\title{
Gazete Köşe Yazıları Söyleminde Süreç Seçimi: Toplumsal Cinsiyet ve Politik İdeoloji Etkisi
}

\author{
Ceyda Ekici ${ }^{1}$, Gülsüm Songül Ercan ${ }^{2}$ \\ ORCID ID: ${ }^{10000-0002-7406-3106, ~}{ }^{2} 0000-0002-5392-7008$ \\ ${ }^{1}$ Çanakkale Onsekiz Mart Üniversitesi, Anafartalar Kampüsü A1-Blok Kat 2 17020, Çanakkale \\ ${ }^{2}$ Dokuz Eylül Üniversitesi Edebiyat Fakültesi Dilbilim Bölümü C Blok Ofis No. 143 Tinaztepe \\ Yerleşkesi Buca/İzmir \\ ${ }^{1}$ ceyda_ekici@hotmail.com, ${ }^{2}$ gsongulercan@gmail.com
}

(Gönderilme tarihi 22 Nisan 2018; kabul edilme tarihi 24 Mayls 2019)

\begin{abstract}
ÖZ: Bu çalışmada bir medya söylem türü olan gazete köșe yazıları incelenerek kadın ve erkek köşe yazarlarının gerçekliğe ilişkin zihinsel temsillerini dil dizgesine aktarımında yaptıkları süreç seçimlerinin bir farklılık gösterip göstermediğinin ve politik ideolojinin söz konusu seçimde bir etmen olup olmadığının ortaya konması amaçlanmıştır. Bu amaç doğrultusunda Dizgeci İşlevsel Dilbilgisi Kuramı temel alınarak, köşe yazıları dilin üstişlevlerinden düşünsel üstişlevin bir alt ulamı olan yaşantısal üstişlevin inceleme alanlarından biri olan geçişlilik dizgesi çerçevesinde çözümlenmiş, yazar cinsiyetinin ve gazetenin benimsediği politik ideolojinin süreç seçimindeki etkisi irdelenmiştir. Çalışmanın bulguları, kadın ve erkek köşe yazarların gerçekliği farklı süreçler aracılığıyla kurguladığını, kadın köşe yazarların, metinlerinde zihinsel, ilişkisel ve davranışsal süreç türlerini, erkek köşe yazarların ise maddesel süreç türünü daha çok yeğlediklerini göstermektedir. Ayrıca gazetenin politik ideolojisinin kadın ve erkek köşe yazarların yaptıkları süreç seçimlerinde etkili olduğu saptanmıştır. Buna göre Laik ve Liberal ideolojide kadın köşe yazarlar, İslami ideolojide ise erkek köşe yazarlar ilişkisel süreçleri daha çok kullanmaktadır.
\end{abstract}

Anahtar sözcükler: toplumsal cinsiyet, Dizgeci İşlevsel Dilbilgisi, geçişlilik, gazete köşe yazıları söylemi, Eleştirel Söylem Çözümlemesi

\section{Process Type Selection in the Discourse of Op-ed Articles: The Effect of Gender and Political Ideology}

ABSTRACT: In this study, it is aimed to find out whether the process type selection of the female and male columnists differ in conveying their mental representations relating reality to the language system and whether political ideology is a factor in this selection by analyzing op-ed articles, a type of media discourse. In line with this objective, the op-ed articles have been analyzed in terms of transitivity system belonging to the experiential metafunction which is the subcategory of ideational metafunction of language in Systemic Functional Grammar and the effects of the columnist's gender and the political ideology adopted by the newspaper in the process choice have been investigated. The findings of the study show that female and male columnists have constructed the reality via different processes, and the female 
columnists have mostly used mental, relational and behavioral process types, while male columnists have frequently used the material process type. Additionally, it has been determined that the political ideology of the newspaper has affected the selection of process types by female and male columnists. Relating to this, in secular and liberal ideology female columnists, and in Islamic ideology male columnists have more frequently used the relational processes.

Keywords: gender, Systemic Functional Grammar, transitivity, discourse of op-ed articles, Critical Discourse Analysis

\section{Giris}

Dil, toplumun tutum ve değerlerini, diğer bir ifadeyle ideolojilerini, yansitan önemli bir araçtır ve aynı zamanda ait olduğu toplumsal ve kültürel yapıda çeşitli kimliklerin ve rollerin yapılandırılmasına, sürdürülmesine aracılık etmektedir (Goddard ve Patterson, 2000: 38-67). Bunlardan biri de toplumsal cinsiyettir. Toplumsal cinsiyet kadın ya da erkek olmaya yönelik psikolojik, toplumsal ve kültürel düzlemde yüklenen anlam ve beklenti farklılıklarını yansıtmaktadır. Çünkü bütün toplumlarda, kadın veya erkek olarak doğmanın ayrımı, toplumsal düzlemde bireylerin davranış biçimlerine etki etmekte ve bunun sonucunda toplumsal cinsiyet öğrenilmiş bir davranışa dönüşmektedir (Lakoff,1975; Christie, 2000; Litosseliti, 2006; Talbot, 2010). Bu açıdan toplumsal pratiklerin bir ürünü olarak toplumsal cinsiyet, yalnızca toplumca kurgulanan cinsiyete özgü roller, ilişkiler ve beklentilerle değil aynı zamanda toplumsal düzende kurumlar aracılığılla belirlenen kadın ve erkek arasındaki güç ilişkilerinin nasıl kurgulandığ ve devam ettirildiğine ilişkin çeşitli gönderim veya sezdirimlerle de ilişkilidir (Butler, 1999; Ercan, 2003). Toplumsal cinsiyet, toplumsal ve kültürel düzenin bireylere yüklediği duygu, düşünce, inanç, değer ve davranış kalıpları bağlamında biçimlenmekte ve kültürel ve toplumsal değerlerle iç içe geçmiş olan dil aracilığıyla, başka bir ifadeyle söylem aracilığıyla sürekli biçimde üretilmekte, yeniden üretilmekte ve güçlendirilmektedir (Goddard ve Patterson, 2000: 38-67). En genel tanımlamayla sözlü ya da yazılı dil kullanımı olarak tanımlanan söylem, toplumsal bir pratiktir. Söylemler toplumsal varlıkları ve ilişkileri hem temsil etmekte hem de onları yapılandırmakta ve yeniden üretmektedir. Söyleme bu türden bir toplumsal kurgulama yaklaşımı, söyleme toplumsal kimlikleri ve ilişkileri, toplumun bilgi ve inanç sistemlerini düzenekleyen, sürdüren ve yeniden üreten bir nitelik kazandırmaktadır (Fairclough, 1992, 3-9).

Yapılan çalışmalar, bireylerin farklı cinsiyet rollerini farklı dilsel seçimlerle sergilediğini göstermektedir. Söz konusu farklılıklar statü ve güç olguları bağlamında biçimlenen toplumsal yapının içine yerleşmiş olan dilsel farklılığa gönderimde bulunmaktadır. Başka bir deyişle, toplumsal cinsiyete özgü dilsel biçemlerin toplumda erkek egemen yapı bağlamında oluştuğu ve bunun 
sonucunda toplumda kadın ve erkek olmaya yönelik bazı farklılıkların bulunduğu varsayılarak toplumdaki hiyerarşi ve eşitsizliğin desteklendiği ileri sürülmektedir (Eckert ve Ginet, 2003: 228; Holmes, 2008: 159-165). Örneğin, kadından beklenen ölçünlü dil kullanımı, kibarlık, argo kullanımından kaçınma gibi her türlü dilsel davranış, toplumsal cinsiyet rollerine yerleşen ve çeşitli sınırlılıkları içeren farklı toplumsallaşma örüntülerini göstermektedir (Holmes, 2008: 157-158). Söz konusu dilsel seçimler kadının toplumsal yapıda boyun eğen ve edilgen rolünü vurgulayan alt konuma yerleştirilmesiyle ilişkilendirilmektedir (Lakoff,1975: 79-81; Edwards, 2009: 129-135). Türkçede dilbilim alanında dil ve toplumsal cinsiyet ilişkisinin yazılı ya da sözlü metinler üzerinden incelendiği çalışmalar da toplumsal cinsiyete ilişkin söz konusu kalıp yargıları destekler niteliktedir (bkz. Ağaçsaban, 1988; Duman, 1991; König, 1992; Aliefendioğlu, 1994; Subaşı Uzun, 1996; Baysal, 1997; Bayyurt, 1999; Ercan, 2003; Yüksel, 2004; Hatipoğlu, 2006; Şimsek, 2006; Yağcioğlu ve Ercan, 2006; Yetkiner Kansu, 2006; Baş, 2009; Ercan, 2012; Gazioğulu Terzi, 2013; Kaya, 2013; Erdoğan, 2014; Sebzecioğlu ve Özgür, 2015; Kaplan, 2016; Büyükkantarcıoğlu ve Duman, 2016). Bu çalışmalara ek olarak toplumsal cinsiyetin sosyolojik ve psikolojik düzlemde ele alındığı çalışmalarda da toplumsal cinsiyete özgü yukarıda bahsedilen rol ve kimliklere ilişkin benzer sonuçlar ortaya konmuştur (bkz. Dökmen, 1999; Beydoğan, 2001; Vatandaş, 2007; Çankaya, 2013; Öngen ve Aytaç, 2013; Bingöl, 2014; Gümüşoğlu, 2014; Vargün, 2016; Dökmen, 2017; Kamışlı, 2018). Bu çalışmalarda kadının toplum, iş ve aile yaşantısında alt konuma indirgenmesi, otoriteden uzak konumu, toplumsal alanda daha sınırlı yer alma, daha çok duygusal ve daha az mantıklı davranış sergileme gibi toplumca yaygın olarak paylaşılan kalıp yargıların nasıl üretildiği ve toplumsallaşma sürecinde sürekli biçimde nasıl içselleştirildiği ele alınmıştır. Toplumsal cinsiyete ilişkin toplumca geliştirilen ve toplumca paylaşılan bu yargılar sosyo-kültürel ve politik yapıya, başka bir ifadeyle "ideolojiye" dayanmaktadır. Gazete köşe yazıları da ideolojilerin yapılandırıldı̆̆ 1 , devam ettirildiği ve yeniden yapılandırıldığı bir medya söylem türüdür (van Dijk,1988: 176).

Gazete köşe yazıları yayımlandığı gazetenin ideolojisi doğrultusunda yazarların ele aldığ 1 güncel ve politik konuları içermekte ve toplum gündemini oluşturan olayların yazarın ait olduğu gazetenin ideolojisiyle örtüşerek belli bir konuda oluşturduğu ve okuyucuya dünyada olup bitenlerle ilgili bilgi sahibi olmalarını sağlayan düşünceler sunmaktadır (van Dijk, 1996). Köşe yazarları da metni yapılandırırken kendi dünya görüşlerini, diğer bir deyişle, benimsedikleri ideolojileri, metne kodlamakta ve okuyucu kitlesini belirli yönde etkilemeyi ve belirli anlamları ön plana çıkarmayı amaçlamaktadır (Chen, 2005: 34). Bu açıdan değerlendirildiğinde, yazarların toplumsal cinsiyet rollerinin metinlerine etki ettiği ve söz konusu rolleri metinlerine yansıttıkları savlanabilir. 
Medyanın toplumun kültürünü ve yaşantısallıkların tözünü biçimlendiren söylemleri nasıl oluşturduğu ve bu bağlamda yapılandırılan söylemin sözcüksel, dilbilgisel ve metinsel özellikleri eleştirel yaklaşımla ortaya konmaktadır (Talbot, 2007: 3-4; Bloor ve Bloor, 2007: 230). Eleştirel Söylem Çözümlemesi (ESÇ) 1rk, siyaset, toplumsal cinsiyet ve kimlik gibi toplumsal ve kültürel etmenlerin, söylem aracılığıyla nasıl yansıtıldığını, hangi sezdirimler aracılığıyla gerçekleştiğini (Paltridge, 2006: 178-179) ve böylece toplumsal bağlamlarda söylemin güç ve gücün kötüye kullanılmasına nasıl aracılık ettiğini açığa vurmayı hedeflemektedir (van Dijk, 2008), Bu, metinde yalnızca açık olarak verilene değil aynı zamanda örtükleştirilmiş ya da gizil olarak verilmiş olana da odaklanmayı, dolayısıyla metnin satır aralarının okunması gerektiği anlamına gelmektedir (Fairclough, 2003: 11). Bu açıdan ESÇ'nde hem dilsel hem de toplumsal çözümlemeye odaklanılarak metin, temel alınmaktadır. Çünkü toplumsal olayın bileşeni olarak metinler ideolojik açıdan biçimlenmekte ve metnin biçimi ve içeriği ideolojik süreçlerin ve yapıların izdüşümlerini taşımaktadır (Fairclough, 1992).

ESÇ metinde örtükleştirilmiş ya da gizil olarak bulunan ideolojiyi açığa çıkarmak amacıyla "yapı-bozumu" olarak adlandırılan bir çözümleme yöntemi kullanmakta; böylece metni bileşenlerine ayırarak anlamı ortaya çıkarmaktadır. Söz konusu yöntemde kullanılan kuramlardan biri de metindeki dilbilgisel yapının ya da sözcük seçimlerinin çözümlenerek metnin satır aralarına gizlenmiş olan sezdirimlerin saptanmasına olanak tanıyan Dizgeci İşlevsel Dilbilgisidir (DİD) (Bloor ve Bloor, 2007: 11). DİD dilbilgisel yapının dizgesel ve kuramsal çözümlemeler aracılığıyla irdelenerek metinde örtükleştirilmiş anlamların açığa kavuşmasında ESÇ’ye destek sağlamaktadır. Hem ESÇ hem de DİD dili toplumsal bir pratik olarak kabul etmekte ve bu açıdan dil ve bağlam arasındaki ilişkiye odaklanarak dili edimsel amaçlarla inceleme noktasında birleşmektedir (Hart, 2014: 5-6).

Yukarıda belirtilen bilgiler 1şı̆̆ında, bu çalışmada gazete köşe yazıları söyleminde (i) süreç türleriyle köşe yazarlarının toplumsal cinsiyet rolleri arasında bir ilişki olup olmadığı; (ii) gazetenin benimsediği politik ideolojinin yazarların süreç seçimini etkileyip etkilemediğinin ortaya konması amaçlanmaktadır. Bu amaç kapsamında DİD Kuramı temel alınarak, köşe yazıları dilin üstişlevlerinden düşünsel üstişlevin bir alt ulamı olan yaşantısal üstişlevin inceleme alanlarından geçişlilik dizgesi çerçevesinde çözümlenmiştir. Alanyazında politik ideolojinin gazete köşe yazıları söyleminde nasıl kurgulandığının geçişlilik dizgesi bağlamında incelendiği çalışmalar bulunmaktadır (bkz. Değer, 1998; Oktar, 1998; Değer ve Oktar, 1999; Matu, 2008; Baykal 2014). Değer (1998) ve Oktar (1998) 'Sürekli aydınlık için bir dakika karanlık eylemi' süresince sekiz farklı günlük gazete yer alan köşe yazılarının Hodge ve Kress modeli bağlamında geçişlilik dizgesini incelemişler ve gerçekliğin farklı süreç türleri aracılığıyla kurgulanarak ideolojik açıdan 
nasıl biçimlendirildiğini saptamışlardır. Değer ve Oktar (1999) gazete köşe yazılarının Hodge ve Kress modeli kapsamında kiplik dizgesini incelemişler ve olayın destekçisi olma bağlamında köşe yazarlarının belirli yargılarda ve sınıflandırmalarda bulunma ve ayrıca ideolojik gücü vurgulama amacıyla ilişkisel dizimler aracılığıyla gerçekliği dil dizgesine aktardıklarını ortaya koymuşlardır. Matu (2008) Kenya'da gazete söyleminin politik ideoloji bağlamında nasıl yapılandırıldığını ortaya çıkarmak için incelediği haber başlıklarında politik gücün yansıtılması ve politik aktörlerin kurgulanması amacıyla daha çok maddesel sürecin kullanıldığını ortaya koymuştur. DİD yaklaşımı bağlamında Baykal (2014) medya söylemini incelediği çalışmasında, farklı ideolojik görüşün temsilcisi olan Cumhuriyet ve Zaman gazetelerindeki köşe yazılarında o dönem Başbakan olan Erdoğan'ın Davos çıkışını konu alan metinleri geçişlilik dizgesi çerçevesinde çözümlemiş ve metinlerde kullanılan süreç türü farklılıklarına ve buna bağlı olarak değişen katılımcı rollerine ilişkin olarak politik ve ideolojik görüşün yapılandırılmasını yansıtan dilsel seçimleri saptamıştır. Bir sonraki bölümde DİD ve geçişlilik dizgesi ele alınmaktadır.

\section{Dizgeci İşlevsel Dilbilgisi ve Geçişlilik}

DİD, dili toplumsal ve işlevsel bir olgu olarak ele almakta ve insanların dili farklı bağlamlarda nasıl kullandığını ve bir göstergeler dizgesi olan dilin farklı işlevleri gerçekleştirmek için nasıl yapılandırıldığını açıklamayı amaçlamaktadır. DİD tümcelerin oluşumunda ve metinlerin düzenlenmesinde, dilin yerine getirdiği işlevleri ve bağlamsal özellikleri anlamsal, edimsel ve sözdizimsel boyutlarıyla inceleyen bir yaklaşımdır (Halliday ve Matthiessen, 2004). DİD dili işlevsel, metinleri de gerçekliğin eşzamanlı temsili olarak kabul etmekte ve toplumsal ilişkilerin belirlenmesi ve toplumsal kimliklerin kurgulanmasında dilin işlevselliğinin önemine vurgu yapmaktadır (Halliday, 1978'den akt. Fairclough, 1992:8-9). Çünkü dil, insanların gereksinimleri çerçevesinde değişen ve gelişen bir olgudur ve bu gereksinimleri karşılamak üzere oluşan yapılanma belli bir işlevi gerçekleştirmeye yöneliktir. Dilin en temel işlevi de anlam üretmektir (Eggins, 2004: 11). DİD’e göre anlam, dil dizgesinde (i) kişilerarası üstişlev, (ii) metinsel üstişlev ve (iii) düşünsel üstişlev olmak üzere üç temel üstişlev aracılığıyla düzenlenmekte ve her bir üstişlev sözlük-dilbilgisi katmanından yapılan seçimlerle anlamsal düzlemde gerçekleşmektedir (Halliday ve Matthiessen, 2004).

$\mathrm{Bu}$ çalışmada temel alınan düşünsel üstişlevde, dil aracılığıyla anlama dönüşen deneyimlerin dilbilgisel dizgede nasıl kodlandığı ve bunun için dilin sözlük-dilbilgisi katmanından yapılan seçimlerin kaynak olarak nasıl kullanıldığı incelenmektedir. “Temsil olarak anlam’’ın ele alındığı düşünsel üstişlevde, bireylerin konuşurken ya da yazarken seçtikleri her tümce ya da sözcük anlam içeriğinin zihinsel olarak nasıl temsilleştirildiğini göstermektedir. 
$\mathrm{Bu}$ açıdan düşünsel üstişlev deneyimlerin ne türden temsilleştirme örüntüsü taşıdığına odaklanarak hem dil içi hem de dil dışı bağlamda insanların dil aracılığıyla gerçekliğin zihinsel temsillerini nasıl oluşturduklarını ortaya koymaktadır (Halliday, 1985: 1; Simpson, 1993: 88; Halliday, 1994; 106; Halliday ve Matthiessen, 2004: 29).

DİD yaklaşımında düşünsel üstişlev mantıksal ve yaşantısal olmak üzere iki ulama ayrılmaktadır. Mantıksal üstişlev dil dizgesi içinde kurgulanan tümcelerin girişik tümceye dönüştürüldüğünde ne türden değişikliklerin ortaya çıktığına ve düşünceler arasındaki ilişkilere açıklık getirmektedir (Halliday ve Matthiessen, 2004: 29; Bloor ve Bloor, 2004: 193-196). Çalışmamızın inceleme nesnesi olan yaşantısal üstişlev ise, dilbilgisel dizge içinde deneyimlerin anlamlandırılmasıyla ilişkilidir. Deneyimler etrafımızda gelişen olaylar ve eylemlerle oluşturduğumuz dışşal deneyimler ve algısal, duyuşsal olguların bilinç dünyamızda gerçekleşmesiyle oluşan içsel deneyimler bağlamında ulamlanmakta ve dilbilgisel dizgede 'süreç' ulamıyla kodlanmaktadır. Düşünsel üstişlevin alt ulamı yaşantısal üstişlevde süreç ulamıyla kurgulanan yaşantısal anlamların ortaya çıkarılmasındaki temel dizge geçişliliktir. Geçişlilik, süreçlerin, olayların, zihinsel işlemlerin ve ilişkilerin dilbilgisidir. Geçişlilik dizgesi, süreç türleri aracılığıyla dış dünyaya ilişkin deneyimlerin somutlaştırılmasını ve böylece farklı deneyimler sonucunda tümcenin dilbilgisel yapısında ortaya çıkan ayrılmayı göstermektedir. Çünkü yapılan her süreç seçimi süreç ve katılımcı rolleri arasındaki ilişkiye de bağlı olarak yaşantısal anlamı farklı açılardan biçimlendirmekte ve sonucunda farklı bir şemayı ya da farklı bir dilbilgisel biçimlenmeyi yansıtmaktadır (Halliday ve Matthiessen, 2004: 168-170). Buna bağlı olarak da, farklı süreç türleri ve katılımcı rolleri içeren tümceler, metin içinde deneyimlerin farklı yorumlanmasını ve anlamlandırılmasını ve böylece toplumsal gerçekliğin farklılaşan yönlerinin açığa çıkmasını sağlamaktadır (Halliday ve Matthiessen, 2004: 174). Geçişlilik dizgesinde somutlaştırılan deneyimler söylem yapısındaki güç ve ideoloji ilişkilerine yönelik önemli eğilimler ve yargılar içermektedir (Matu, 2008: 200). Bu açıdan geçişlilik çözümlemesi, metinlerin toplumsal güdülenmelerini kültürel ve ideolojik etmenler bağlamında açıklamaya ve söylemde gerçekliğin gösterimini sunmak için seçilen süreç türünün taşıdığı anlamları betimlemeye odaklanmaktadır (Fairclough, 1992: 179-180). Süreç ulamı çerçevesinde tümcenin geçişlilik dizgesinin çözümlenmesi (i) süreç, (ii) katılımcı ve (iii) çevresel üye olmak üzere üç bileşen içermektedir. Süreç tümcede eylem grubu aracılığıyla kodlanmakta ve önermenin düzenlenişi hakkında bilgi vermektedir. Katılımcılar süreçte yer alan varlıklardır ve tümcede ad grubu ile kodlanmaktadır. Olay durumu hakkında daha detaylı bilgi veren çevresel üye ise, belirteç grubu ya da ilgeç öbeğiyle kodlanmaktadır (Halliday ve Matthiessen, 2004:169). 
(1) Ayşe iki saattir ağliyor

KATILIMCI ÇEVRESEL ÜYE SÜREÇ

Örnek (1)'de gösterildiği gibi ă̆llyor süreç, Ayşe sürecin katılımcısı ve $i k i$ saattir sürecin zaman gösteren çevresel üyesidir. Bu çalışma katılımcı rolleri odaklı bir çalışma olmadığı için aşağıda süreç türlerinden bahsedilmiştir.

Halliday ve Matthiessen (2004), süreçleri maddesel (material), zihinsel (mental) ve ilişkisel (relational) olmak üzere üç temel; davranışsal (behavioral), sözel (verbal) ve varlıksal (existential) olmak üzere üç de alt ulama ayırmaktadir.

- $\quad$ Maddesel süreç, koş-, gel-, düş-, ara- gibi devinim bildiren eylemleri içeren süreç türüdür (Halliday ve Matthiessen, 2004: 180).

- Zihinsel süreç, kendi bilinç ya da psikolojik durumlarımızla düşünceler, duygular ve algılar çerçevesinde dünyayı anlamlandırdığımız ya da deneyimlediğimiz süreç türüdür (Eggins, 2004: 225). Zihinsel süreçler, 'düşünme', 'bilme', 'anlama' gibi bilişsel eylemler; 'sevme', 'nefret etme', 'korkma' gibi duyuşsal eylemler; 'görme', 'duyma' gibi algısal eylemler olmak üzere üç ulama ayrılmaktadır (Halliday ve Matthiessen, 2004: 201-212).

- İlişkisel süreç, bir şeyi bir şeyle özdeşleştirme ya da bir şeyi tanımlama için kullanılan süreç türüdür ve 'olma' eyleminin niteleme ve tanımlama olmak üzere iki farklı biçimiyle gerçekleşmektedir. (Halliday ve Matthiessen, 2004: 214-216).

- Sözel süreç, zihinsel ve ilişkisel süreçlerin arasında yer alır ve 'sorma', 'anlatma', 'söyleme' gibi sözel eylemleri içermektedir. (Eggins, 2004:235; Halliday ve Matthiessen, 2004: 251-253).

- Davranışsal süreç, öksür-, gül-, ağla-, nefes al-, kaş çat- gibi maddesel ve zihinsel süreçlerin arasında yer alan fizyolojik ve psikolojik durumları içeren süreç türüdür (Eggins, 2004:233; Halliday ve Matthiessen, 2004: 248-251).

- Varlıksal süreç, bir şeyin var olduğunu ya da bir şeyin meydana geldiğini belirten süreç türüdür (Bloor ve Bloor, 2004:125; Eggins, 2004: 238). Varlıksal süreç türü Türkçede 'var' ve ‘yok' sözcükleriyle biçimlenmektedir.

Alanyazında yukarıda bahsedilen süreç türlerinin toplumsal cinsiyet değişkeni kapsamında incelendiği çalışmalarda süreç türlerinin edimsel açıdan hangi işlevleri yerine getirdiğine ilişkin bir takım saptamalar ortaya konmuştur (bkz. Kamler, 1993; Figueiredo 1998; Gallardo, 2006; Fisher 2011; Khan ve Rahman, 2014; Dai, 2015). Kamler (1993) toplumsal cinsiyet kalıplarını erken 
yaşlardan itibaren nasıl edinildiğini ortaya çıkarmak için yaptığı çalışmasında kız ve erkek çocukların ürettikleri metinlerdeki süreç kullanımını incelemiş ve çalışmanın sonunda erkek öğrencilerin daha çok erkek egemenliği ve güç ilişkileriyle bağıntılı olarak deneyimlerini maddesel süreç aracılığıyla temsilleştirdiklerini ve böylece dünyaya hükmeden aktörler olarak kendilerini tanımladıklarını ortaya koymuştur. Diğer taraftan kız çocuklarının ise, dünya temsillerini daha çok düşünce ve duygu kavramları çerçevesinde zihinsel süreçler aracılığıyla yorumladıklarını ya da sınıflandırma ve niteleme ilişkisi kurarak daha çok gözlemci rolüyle deneyimlerini ilişkisel süreç kullanarak somutlaştırdıklarını saptamıştır. Gallardo (2006) edebi metinlerin toplumsal cinsiyet rollerini yansıttığı savından hareketle yaptığı çalışmasında, Pygmalion adlı tiyatro oyununda kadın ve erkek karakterler tarafından kullanılan dili DİD yaklaşımı bağlamında incelemiş ve söz konusu edebi metinde erkeklerin daha çok ilişkisel süreç aracılığıyla yargılama edinimi, kadınların ise daha çok zihinsel süreç kullanımıyla yorumda bulunduklarını saptamıştır. Fisher (2011) toplumsal cinsiyet ve geçişlilik ilişkisini gazete metinlerinde incelediği çalışmasında, sözel süreç türünün daha çok kadın cinsiyetiyle ilişkilendirilerek (-) değer yüklü olarak 'konuşan kadın' imgesinin yaratıldığını ortaya çıkarmıştır. Dai (2015) toplumsal cinsiyet rollerinin ticari reklamlarda nasıl yapılandırıldığını ele aldığı çalışmasında, bir cep telefonu markasının tanıtımının yapıldığı reklam metnini geçişlilik çözümlemesi bağlamında incelemiş ve telefonun kadınlar arasında da satışını arttırmak için kadının daha çok maddesel süreçler kullanarak kendini 'kılıcı' rolüyle ilişkilendirip kendini gerçekleştirmek için güçlü duygulara sahip, kendi seçimlerini ve isteklerini yapabilen özgür ve toplumsal düzlemde eşit haklara sahip kadın temsilinin vurgulandığını saptamıştır. Figueiredo (1998) tecavüz davalarında alınan temyiz kararlarını geçişlilik kapsamında ele almış ve söz konusu karar metinlerinde temyize giden taraf olarak erkeklerin maddesel süreçler aracılığıyla kararın sorumluluğunu alan ve gücü elinde bulunduran aktörler olarak kendilerini tanımladıklarını ancak kararı şikayet eden rolünde olan kadınların ise, soyut düşünme ve durum tespiti işlevlerine yönelik olarak ilişkisel ve zihinsel süreçler kullandıklarını ve eylemin hareket odağından uzaklaşarak eylemin imgesini yarattıklarını saptamıştır. Phan ve Nguyen (2015) Dizgeci İşlevsel Dilbilgisi çerçevesinde davranışsal süreçlerin İngilizce ve Vietnamcadaki izdüşümlerini inceledikleri çalışmalarında, davranışsal süreçlerde, davranışı gösteren katılımcının, zihinsel süreçlerdeki algılayıcı rolüyle örtüştüğünü ve bu davranışsal sürecin bilinç dünyasına ilişkin anlamları yapılandırıldığını belirtmişlerdir (Phan ve Nguyen, 2015: 348-349). Söz konusu çalışmalar toplumsal cinsiyet ve güç ilişkilerinin asimetrik dağılımını ve toplumdaki erkek hegemonyasının dil aracılığıyla nasıl yapılandırıldığını açığa çıkarmaktadır. 
Bulgular bölümünde buraya kadar bahsedilen süreç türlerinin veri tabanından seçilen örnekleri yer almaktadır. Bir sonraki bölümünde çalışmanın amacı, veri tabanı ve yöntemine değinilmiştir.

\section{Veri Tabanı ve Yöntem}

Giriş bölümünde belirtildiği gibi bu çalışmada, gazete köşe yazıları söyleminde, süreç türüyle köşe yazarlarının toplumsal cinsiyet rolleri arasında bir ilişki olup olmadığının ve gazetenin benimsediği politik ideolojinin yazarların süreç seçimini etkileyip etkilemediğinin ortaya konması amaçlanmaktadır. Bu amaç doğrultusunda 11/12/2016 - 31/12/2016 tarihleri arasında yayımlanan farklı ideolojik görüşlerin temsilcisi olarak bilinen 9 adet günlük gazetede (Cumhuriyet, Aydınlık, Sözcü, Hürriyet, Milliyet, Habertürk, Milat, Yeni Şafak, Yeni Akit) yer alan 1134 adet köşe yazısı arasından seçkili örneklem yöntemiyle seçilen 45'i kadın ve 45'i erkek köşe yazarına ait toplam 90 adet köşe yazısı incelenmiştir. Belirlenen tarihler arasında köşe yazılarında üç temel başlık saptanmıştır. Söz konusu başlıklar Türkiye'de yaşanan terör olaylarl, Suriye'de yaşanan savaş ve Fırat Kalkanı Operasyonu ve son olarak da Rus Büyükelçisi Karlov'a yönelik suikasttir.

Tablo 1. Veri Tabanını Oluşturan Gazete Köșe Yazılarının Dağılımı

\begin{tabular}{ccccccc}
\hline & \multicolumn{2}{c}{$\begin{array}{c}\text { Türkiye'deki Terör } \\
\text { Olayları }\end{array}$} & \multicolumn{2}{c}{$\begin{array}{c}\text { Frrat Kalkanı } \\
\text { Operasyonu }\end{array}$} & \multicolumn{2}{c}{$\begin{array}{c}\text { Rus Büyükelçi Karlov } \\
\text { Suikasti }\end{array}$} \\
\hline \multirow{2}{*}{ Laik } & $\mathrm{K}$ & $\mathrm{E}$ & $\mathrm{K}$ & $\mathrm{E}$ & $\mathrm{K}$ & $\mathrm{E}$ \\
\cline { 2 - 7 } & 5 & 5 & 6 & 6 & 4 & 4 \\
Liberal & 5 & 5 & 6 & 6 & 4 & 4 \\
İslami & 5 & 5 & 6 & 6 & 4 & 4 \\
Toplam & 15 & 15 & 18 & 18 & 12 & 12 \\
\hline
\end{tabular}

Tablo 1'de belirtilen konular bağlamında köşe yazıların sayıları ve gazetelere göre dağılımı verilmektedir.

Toplumsal düzlemde yaşanan ideolojik çatışmalara bağlı olarak medya kurumları da ayrışmıştır. Dolayısıyla köşe yazılarının eşleştirilmesinde ortak konu bağlamı dışında köşe yazılarının yer aldıkları gazetelerin ideolojik görüşü de ölçüt olarak değerlendirilmiş ve gruplandırılmıştır. İdeolojik görüş ayrımından hareketle Türkiye'de Laik, Liberal ve İslami ideolojilerin varlığından söz edilebilir. Bu çalışmanın veri tabanını oluşturan 9 adet günlük gazete temsil ettikleri ideolojilere göre Cumhuriyet, Aydınlık ve Sözcü Laik; Hürriyet, Milliyet ve Habertürk Liberal; Milat, Yeni Akit ve Yeni Şafak ise İslami görüş olmak üzere üç gruba ayrılmaktadır (http://www.0wikipedia.org). 
Veri tabanını oluşturan köşe yazıları geçişlilik dizgesi kapsamında çözümlenerek incelenmiş ve her süreç türünün yazar cinsiyetine göre kullanım oranı belirlenmiştir. Çalışmada toplumsal cinsiyet değişkeninin süreç kullanımına bir etkisi olup olmadığını belirlemek amacıyla iki oran testi, süreç kullanımı ve ideoloji değişkeni arasında bir ilişki bulunup bulunmadığını ortaya koymak amacıyla Ki-kare testi uygulanmıştır. Her süreç türüne ilişkin iki oran testine ait formül şu şekildedir:

- 'Örneklem 1' kadın; 'Örneklem 2' erkek köşe yazarlarının yazılarını;

- 'X' süreç türü kullanım sayısını;

- 'N' gazete köşe yazılarındaki toplam tümce sayısını;

- 'GA' güven aralı̆̆ını;

- 'Örneklem p' ise, yüzde olarak oranlarını ve anlamlılık değerini temsil etmektedir.

Testlerde anlamlılık değeri $a=0.05$ olarak alınmıştır. Test sonucunda bulunan $\mathrm{p}$ değeri $a=0.05$ 'ten küçük ise oranların eşitliği varsayımı reddedilmiştir. Toplumsal cinsiyet değişkenine bağlı süreç türü kullanım oranları arasındaki farkın araştırılmasında ' $\mathrm{H} 0: \mathrm{p} 1-\mathrm{p} 2=0$ ”' ve “' $\mathrm{H} 1: \mathrm{p} 1-\mathrm{p} 2 \neq 0$ ”' varsayımları test edilmiştir. Araştırmanın bulgularını test etmek amacıyla $\mathrm{H} 0$ varsayımı, yani 'kadın ve erkek süreç türü kullanım oranı eşittir' savı oluşturulmuştur. P değeri 0.05 'ten küçük olduğu durumlarda varsayımı reddedilmiş ve bu durumda H1 varsayımı, yani 'kadın ve erkek süreç türü kullanım oranlarının eşit olmadığı' sonucuna varılmıştır. Bu da toplumsal cinsiyet ve süreç türü kullanımı arasındaki farkı göstermektedir. Ayrıca çalışmada, süreç türlerinin toplumsal cinsiyet değişkeni bağlamında farklılık gösterip göstermediğine odaklanıldığı için süreç türleri ve buna bağlı olarak değişen katılımcı rolleri ve çevresel üyeler inceleme dışında tutulmuştur. Buna ek olarak çalışmada yalnızca istatistiksel açıdan anlamlı farkın gözlemlendiği değişkenler arasındaki ilişkiler yorumlanmıştır.

\section{Bulgular ve Tartışma}

Bilindiği gibi, bu çalışmada gazete köşe yazıları incelenmektedir ve DİD çerçevesinde geçişlilik dizgesi kapsamında süreç seçiminin yazar cinsiyeti ve gazetenin benimsediği politik ideoloji ile ilişkisi irdelenmektedir. Bu amaçla aşağıdaki bölümlerde incelenen veri tabanından elde edilen bulgulara, uygulanan istatistiksel testlerin sonuçlarına ve bu sonuçların değerlendirilmesine yer verilmektedir. 


\subsection{Gazete Köşe Yazılarında Süreç Seçimi ve Toplumsal Cinsiyet Rolleri Illişkisi}

Veri tabanını oluşturan köşe yazılarının incelenmesi sonucunda elde edilen bulgular, kadın ve erkek köşe yazarların toplumsal cinsiyet rollerine bağlı olarak süreç seçimlerinin farklılaştı̆ıını göstermiștir. Tablo 2'de yazar cinsiyetine göre her süreç türünün kullanım sıklık ve oranları verilmektedir.

Tablo 2. Yazar Cinsiyetine Göre Süreç Türü Kullanım Sayıları ve Oranları

\begin{tabular}{lcccc}
\hline \multirow{2}{*}{ Süreç Türleri } & \multicolumn{2}{c}{ Tümce sayısı } & \multicolumn{3}{c}{$\%$} \\
\cline { 2 - 5 } & $\mathrm{K}$ & $\mathrm{E}$ & $\mathrm{K}$ & $\mathrm{E}$ \\
\hline Maddesel & 553 & 779 & $\% 35.8$ & $\% 42.5$ \\
Zihinsel & 214 & 210 & $\% 13.8$ & $\% 11.4$ \\
İlişkisel & 532 & 538 & $\% 34.4$ & $\% 29.4$ \\
Sözel & 126 & 160 & $\% 8.1$ & $\% 8.7$ \\
Davranışsal & 38 & 23 & $\% 2.4$ & $\% 1.2$ \\
Varlıksal & 81 & 119 & $\% 5.2$ & $\% 6.5$ \\
Toplam & 1544 & 1829 & $\% 100$ & $\% 100$ \\
\hline
\end{tabular}

Tabloda sayısal olarak gösterilen verilerin istatistiksel olarak anlamlılığını ölçmek amaciyla uygulanan iki oran testi sonucunda P-Değeri 0,05 'ten büyük olduğu için sözel süreç (P-Değeri $=0,541)$ ve varllksal süreç $(\mathrm{P}$-Değeri $=$ $0,119)$ türlerinin kullanım sıklıklarının toplumsal cinsiyet değiş̧eni bağlamında anlamlı bir farklılık göstermediği ortaya konmuştur. Buna karşı1lık P-Değeri 0,05 'ten küçük olduğu için maddesel (P-Değeri= 0,000), zihinsel (P-Değeri= $0,039)$, ilişskisel (P-Değeri $=0,002)$ ve davranışsal (P-Değeri=0,011) süreç türlerinin kullanım oranlarında toplumsal cinsiyet değişkeni kapsamında ortaya çıkan farkın anlamlı olduğu saptanmıştır. Aşağıda sırasıyla maddesel, zihinsel, ilişkisel ve davranışsal süreç türlerinin veri tabanından seçilen örneklerine yer verilmekte ve bulgular toplumsal cinsiyet değişkeni bağlamında yorumlanmaktadır.

(2) 'Ellerinde olsa Tunus'u şeriat anayasası giydireceklerini detaylarıyla yazmıştım.'

(Ceyda Karan, 28.12.2016, Cumhuriyet)

(3) 'Yüzlerce Amerikalının öldüğü Irak Savaşı sırasında ABD basını ölenleri fotoğraflarını neredeyse hiç yayımlamadı.'

(Melis Alphan, 24.12.2016, Hürriyet) 
(4) 'Rus elçisi Andrey Gennadiyeviç'i, eşinin gözleri önünde, sırtından kurşunluyor.'

(Mehtap Y1lmaz, 21.12.2016, Yeni Akit)

Yukarıda örnek (2), (3) ve (4)'te yer alan yaz-, yayımla- ve kurşunla- süreçleri devinimi yansıtan maddesel süreç türüne örnek oluşturmaktadır. Kadın ve erkek köşe yazarlarının yazılarında kullandıkları maddesel sürece ilişkin iki oran test sonucu maddesel sürecin erkek köşe yazarlar tarafından daha çok kullanılan bir süreç türü olduğunu göstermektedir. Dolayısıyla erkek köşe yazarların kadın köşe yazarlara oranla dış dünyaya ilişkin zihinsel temsilleri dil düzlemine aktarırken bir devinimi içeren süreci ve bu süreci gerçekleştiren kılıcı rolünü daha çok vurguladıkları ve böylece olaya ilişkin gerçekliği dil düzlemine aktarımında daha açık ve güçlü söylemi kurguladıkları ileri sürülebilir. Çünkü deneyim kurgulanırken yapılan süreç seçimleri deneyimin odağına ya da çıkış noktasına ilişkin izler taşımaktadır (Kamler, 1993: 98). Maddesel süreçlerin de olayın kurgulanmasında, sürecin işleyişine yön veren, etki eden anlamların tümcede açıkça kodlanmasına aracılık ettiği düşünülürse erkek köșe yazarların metinlerini güç olgusu bağlamında daha baskın biçimlendirdiği belirtilebilir. Maddesel süreçler gerçekliğe ilişkin temsilin daha açık yapılandırılmasıyla bağıntılı olarak gazetenin benimsediği ideolojinin de daha baskın ve açık olarak yansıtılması sağlamaktadır (Matu, 2008: 204). Bu açıdan erkek köşe yazarların medya söyleminde 'güç aktörleri' olarak karşımıza çıktığı öne sürülebilir. Toplumsal cinsiyet ve geçişlilik üzerine yapılan daha önceki çalışmalar da maddesel sürecin kullanımının erkeklerin hem güç söyleminin yaratıcısı hem de gücün aktörleri olarak toplumsal düzlemde yer aldıklarını destekler niteliktedir (bknz. Kamler, 1993; Gallardo, 2006; Matu, 2008; Fisher 2011; Khan ve Rahman, 2014).

(5) 'Bunların bombalı eylem, canlı bomba eylemlerini gerçekleștirecekleri de biliniyor.'

(Sayg1 Öztürk, 13.12.2016, Sözcü)

(6) 'Trump göreve başlamadan Halep'i düşürmek, temizlemek, yok etmek istediler.'

(Nihal Bengisu Karaca, 15.12.2016, Habertürk)

(7) 'Kendisini Türkiye sınırları dışına atabilenler kendisini güvende hissetmemeli.'

(Yaşar Baş, 12.12.2016, Yeni Akit)

Yukarıdaki tümcelerde karşımıza çıkan bil-, iste- ve hisset- süreçleri, deneyimlere ait gerçekliğin algılama, düşünme ve duygulanım bağlamında bilinç dünyasında kodlanmasıyla gerçekleştirilen zihinsel süreç türüne örnek oluşturmaktadır. Kadın ve erkek köşe yazarlarının yazılarında kullandıkları 
zihinsel sürece ilișkin iki oran test sonucu zihinsel sürecin kadın köșe yazarlar tarafından daha çok kullanılan bir süreç türü olduğunu göstermektedir. Bu açıdan kadın köşe yazarların erkek köşe yazarlara oranla dış dünya deneyimlerini, metin düzlemine daha çok duygu, düşünce ve algı gibi bilinç dünyasına ilişkin anlamlandırmalar aracılığıyla aktardığı ve dolayısıyla da kadın köşe yazarlarının, deneyimin kurgulanmasında sürecin kim tarafından ve nasıl gerçekleştiğinin vurgulanmasından uzaklaşarak, gerçekliği düşünsel ve yorumsal boyutta kurguladıkları öne sürülebilir. Başka bir ifadeyle bu durum kadınların, toplumsal cinsiyet rolleriyle de ilişkili olarak, deneyimlerini metin düzlemine aktarırken duygusal bir duruş ve tutum sergilediklerini ve gerçekliği kurgularken eylemden uzaklaşarak, yani eylemi görünmez kılarak farklı açılardan yorumladıkları göstermektedir. Çünkü zihinsel süreçler durağan bir durumun imgesini yaratma ve durumun betimlenmesi ve yorumlanması işlevini yerine getirmektedir (Kamler, 1993: 99; Figueiredo, 1998: 98). Bu bağlamda deneyimin kurgulanmasındaki çıkış noktasının 'duygular' olduğu (Halliday, 1985) bu açıdan erkek meslektaşlarından farklılaştıkları görülmektedir.

(8) 'Suriye krizinin Türkiye' ye etkileri tahmin ettiğimizden bile büyük olabilir.'

(Zeynep Gürcanl1, 19.12.2016, Sözcü)

(9) 'Her terör eylemi, daha sıkı güvenlik önlemi, polis devletine doğru bir adım daha yaklaşmak anlamına geliyor.'

(Murat Yetkin, 12.12.2016, Hürriyet)

(10) 'Türkiye'nin veya Rusya'nın tam da bu süreçte, birlikte böyle bir saldırıya maruz kalmalarını tamamen alakasız görmemek gerekiyor.'

(Yasin Aktay, 24.12.2016, Yeni Şafak)

Örnek tümcelerde yer alan ol-, anlamına gel-ve gerek- süreçleri öğeler arasında tanımlama ilişkisi kurmakta ve ilişkisel süreç kapsamında değerlendirilmektedir. Kadın ve erkek köşe yazarlarının yazılarında kullandıkları ilişkisel sürece ilişkin iki oran test sonucu ilişkisel sürecin kadın köşe yazarlardan tarafindan daha çok yeğlenen bir süreç türü olduğunu göstermektedir. Kadın köşe yazarların erkek köşe yazarlara oranla deneyimlenen gerçekliğe ilişkin temsili, niteleme ya da tanımlama ilişkisi kurarak daha çok soyut ilişkiler dünyasıyla bağıntılı olan anlamlandırmalar aracılığıyla yapılandırdıkları ileri sürülebilir. Bu durum kadın köşe yazarlarının daha çok 'gözlemci' rolü üstlenerek deneyimi olgular arasında bir takım betimleme, niteleme ve tanımlama ilişkileri kurarak somutlaştırdıklarını ve durum tespiti yaptıklarını göstermektedir ki söz konusu dilsel yapılanmalar erkek söyleminde daha az karşımıza çıkmaktadır (Kamler, 1993: 98-99; Matu, 2008: 201). Diğer taraftan iliş̧kisel süreçler tümcede niteleme ilişkisi bağlamında sınıflandırma ve yargılama edimlerini de yerine getirmektedir. Söz 
konusu edimler zihinsel etkinliklerin sonuçlarına gönderimde bulunabilir, çeşitli yargılar öne sürebilir ya da açıklamalar sunabilir. Bu tür dilsel yapılanmalar ya da düzenekler de gerçekliğe ilişkin düşüncelerin çeşitli sezdirimler aracılığıyla yönlendirilmesini ve temsillerin farklı biçimde kurgulanmasını içermektedir (Hodge ve Kress, 1993: 9-12; Oktar, 2001: 325). Ayrıca gerçekliğin bir takım sezdirimsel yapılar aracılığıyla inşası, kadın köşe yazarlarının söz konusu süreç türünü bilgiyi paketleme stratejisi olarak kullandıkları ve böylece metinde daha örtük anlamları yapılandırdıkları biçiminde yorumlanabilir. $\mathrm{Bu}$ durum da, kadın köşe yazarlarının toplumsal cinsiyet rolleriyle bağlantılı olarak çatı̧̧madan kaçınma davranışı sergilediklerinin göstergesi olabilir.

(11) 'Bugünün karanlık oyunlarını da gün gelecek korkunç bir masal dinler gibi dinleyeceğiz.'

(12) 'Suratlarına gülüyorum.'

(Mine Söğüt, 14.12.2016, Cumhuriyet)

(Gülse Birsel, 13.12.2016, Hürriyet)

(13) 'Bir asker, kundağa sarılı bir bebeğin naaşı başında gözyaşı döküyor.'

(Mehtap Yılmaz, 16.12.2016, Yeni Akit)

Tümcelerde yer alan dinle-, gül- ve gözyaşı dök-süreçleri davranışsal süreç türüne örnek oluşturmaktadır. Kadın ve erkek köşe yazarlarının yazılarında kullandıkları davranışsal sürece ilişkin iki oran test sonucu kadın köşe yazarların davranışsal süreç türünü daha çok kullandıklarını göstermektedir. Maddesel ve zihinsel süreçlerin arasında yer alan ve psikolojik ve fizyolojik durumları içeren davranışsal süreç, insanların zihinsel ve sözel davranışlarının anlamlandırılmasını ve yorumlanmasını içermektedir. Davranışsal süreçlerde 'davranışı gösteren' katılımcı, zihinsel süreçlerdeki 'algılayıcı' rolünü üstlenerek bilinç dünyasına ilişkin anlamları yapılandırmaktadır (Phan ve Nguyen, 2015: 348-349). Bu açıdan kadınların, tıpkı zihinsel süreçlerde olduğu gibi duyu ve algı edimleri çerçevesinde gerçekliği kurgulayarak (Kamler, 1993: 99) deneyimleri metinde somutlaştırırken duygusal bir düzleme yerleştirdikleri düşünülebilir. Bu durumun kadın köşe yazarlarının toplumsal cinsiyet rolleriyle örtüşen 'duygusal' kimliklerini metin yazarı olarak da sürdürdükleri ve toplumsal rollerini tür rollerinde de sürdürdükleri biçiminde yorumlanabilir.

Şekil 1'de süreç türlerinin köşe yazarlarının toplumsal cinsiyetleri bağlamında kullanım dağılımları gösterilmektedir. 
Şekil 1. Süreç Türlerinin Toplumsal Cinsiyete Göre Dağıllım

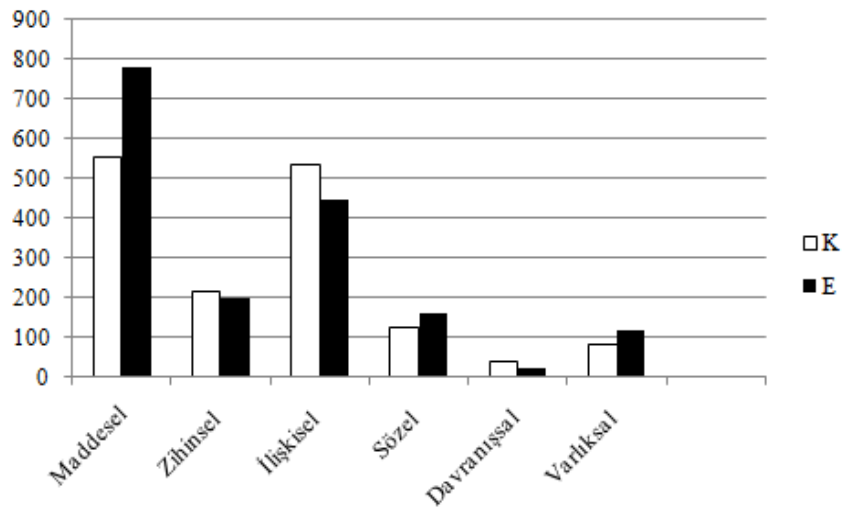

$\mathrm{Bu}$ sonuçlardan yola çıkarak kısaca gazete köşe yazarlarının toplumsal cinsiyetleri bağlamında dış dünya deneyimlerine ait zihinsel şemaları dil dizgesinde kurgularken, gerçekliğin temsilini farklı süreç türleri aracıllğıyla yapılandırdıklarına ve böylece toplumsal cinsiyet rollerinin herhangi bir olaya ya da olguya ilişkin anlamın oluşuma etki ettiği savlanabilir.

\subsection{Gazete Köşe Yazılarında Süreç Seçimi ve Politik İdeoloji İlişkisi}

Çalışmamızın bulguları gazetelerin benimsedikleri politik ideolojinin süreç seçimindeki etkisi olup olmadığının ortaya konması amacıyla irdelendiğinde ise kadın ve erkek köşe yazarların ilişkisel süreç kullanımlarının gazetenin ideolojisi kapsamında "anlamlı" farklılık gösterdiği saptanmıştır. 
Tablo 3. Süreç Türlerinin Toplumsal Cinsiyet ve İdeoloji Bağlamında Dă̆ılımı

\begin{tabular}{|c|c|c|c|c|c|c|c|c|c|c|c|c|}
\hline & \multicolumn{4}{|c|}{ LAİK } & \multicolumn{4}{|c|}{ LİBERAL } & \multicolumn{4}{|c|}{ İSLAMİ } \\
\hline & \multicolumn{2}{|c|}{ SIKLIK } & \multicolumn{2}{|c|}{$\%$} & \multicolumn{2}{|c|}{ SIKLIK } & \multicolumn{2}{|c|}{$\%$} & \multicolumn{2}{|c|}{ SIKLIK } & \multicolumn{2}{|c|}{$\%$} \\
\hline & $\mathrm{K}$ & $\mathrm{E}$ & $\mathrm{K}$ & $\mathrm{E}$ & $\mathrm{K}$ & $\mathrm{E}$ & $\mathrm{K}$ & $\mathrm{E}$ & $\mathrm{K}$ & $\mathrm{E}$ & $\mathrm{K}$ & $\mathrm{E}$ \\
\hline 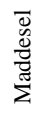 & 184 & 283 & 33 & 43.4 & 202 & 280 & 36.5 & 48.6 & 167 & 216 & 38.3 & 35.8 \\
\hline 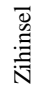 & 75 & 58 & 13 & 8.9 & 69 & 73 & 12.4 & 12.6 & 70 & 79 & 16 & 13.1 \\
\hline 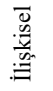 & 217 & 179 & 39 & 27.4 & 185 & 144 & 33.4 & 25 & 130 & 215 & 29.8 & 35.6 \\
\hline $\begin{array}{l}\overline{\mathcal{N}} \\
: 0 \\
\text { D }\end{array}$ & 46 & 76 & 8.2 & 11.6 & 58 & 47 & 10.4 & 8.1 & 22 & 37 & 5 & 6.1 \\
\hline 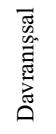 & 11 & 15 & 1.9 & 2.3 & 10 & 3 & 1.8 & 0.5 & 17 & 5 & 3.9 & 0.8 \\
\hline 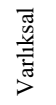 & 23 & 40 & 4.1 & 6.1 & 29 & 28 & 5.2 & 4.8 & 29 & 51 & 6.6 & 8.4 \\
\hline oplan & 556 & 651 & 100 & 100 & 553 & 575 & 100 & 100 & 435 & 603 & 100 & 100 \\
\hline
\end{tabular}

Tablo 3'te maddesel, zihinsel, ilişkisel, sözel, davranışsal ve varlıksal süreç türlerinin toplumsal cinsiyet ve ideoloji değişkenleri bağlamında kullanım sıklıkları gösterilmektedir. Tabloda yer alan veriler Ki-kare testi uygulanarak çözümlenmiştir.

İlişkisel süreçlere ilişkin Ki-kare test sonucunda (Ki-kare=29,665) ilişkisel sürecin Laik ve Liberal ideolojide kadın yazarlar tarafından daha çok 
kullanılmasına karşın İslami ideolojide erkek köşe yazarlar tarafindan daha çok kullanıldığı sonucuna ulaşılmıştır. Diğer taraftan üç farklı ideoloji ve yazarın toplumsal cinsiyeti kapsamında maddesel süreç ( $\mathrm{p}$-değeri $=0,454>\alpha=0.05, \mathrm{Ki}$ kare $=1,579$ ), zihinsel süreç ( $\mathrm{p}$-değeri $=0,248>\alpha=0.05$, Ki-kare $=2,792)$, sözel süreç (p-değeri $=0,015>\alpha=0.05, \mathrm{Ki}-\mathrm{kare}=8,420)$, davranışsal süreç ( $\mathrm{p}$ değeri $=0,021>\alpha=0.05, \mathrm{Ki}-\mathrm{kare}=7,708)$ ve varlıksal süreç (p-değeri=0,168> $\alpha=0.05, \mathrm{Ki}-\mathrm{kare}=3,563$ ) türlerinin kullanımında değişkenler arasındaki ilişskinin Ki-kare testine göre " anlamlı olmadı̆̆ı"' gözlenmiştir.

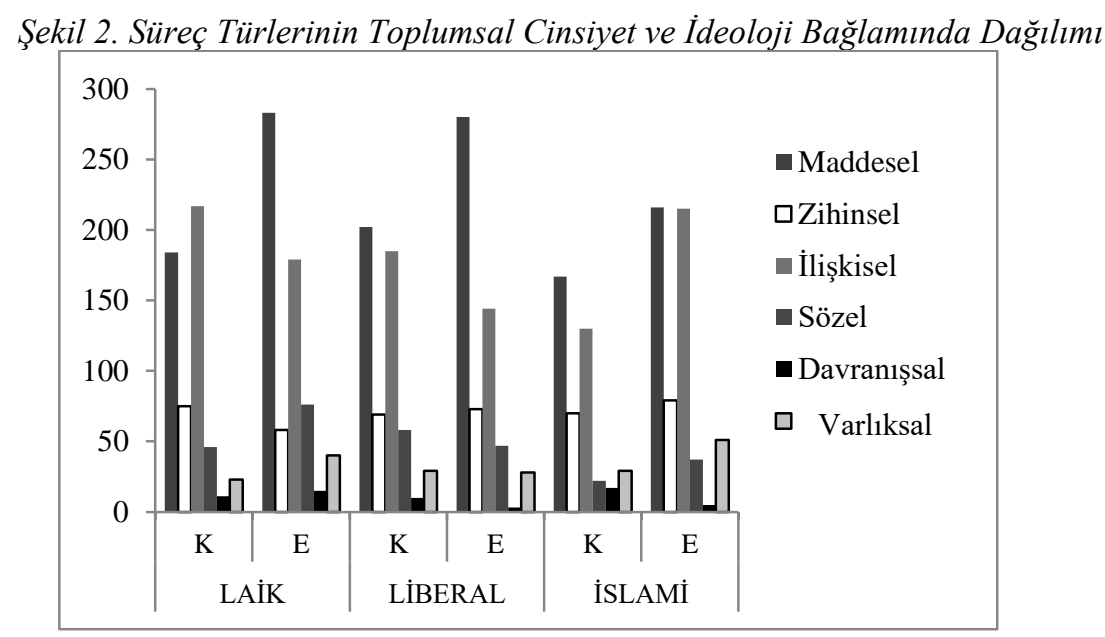

Şekil 2'de süreç türlerinin toplumsal cinsiyet ve ideoloji bağlamında kullanım dağılımları çubuk diyagramda gösterilmektedir.

İlişkisel sürecin farklı politik ideolojileri benimseyen gazetelerde farklı toplumsal cinsiyet gruplarınca kullanılması gazetenin benimsediği politik ideolojinin toplumsal cinsiyet ideolojisine etki ettiği ve Laik ve Liberal ideolojide kadın yazarların, İslami ideolojide ise erkek yazarların ilişkisel süreçler aracılığıyla güç ideolojisinin göstergesi olarak bir takım yargılama ve sınıflandırma edimlerini gerçekleştirdikleri biçiminde yorumlanabilir (Değer ve Oktar, 1999).

\section{Sonuç}

Gazete köşe yazıları söyleminde, süreç türüyle köşe yazarların toplumsal cinsiyet rolleri arasında bir ilişki bulunup bulunmadığının ve gazetenin benimsediği politik ideolojinin yazarların süreç seçimini etkileyip etkilemediğinin ortaya konmasının amaçlandığı bu çalışmada elde edilen bulgular hem kadın ve erkek köşe yazarların süreç seçimlerinin toplumsal 
cinsiyet rolleriyle bağıntılı olarak farklılık gösterdiğini hem de politik ideolojinin söz konusu seçimde etkili olduğunu göstermektedir.

Çalışmanın bulguları, toplumsal cinsiyet değişkeninin geçişlilik dizgesinden yapılan seçimlere etki etki ettiğini ve kadın ve erkek köşe yazarların dış dünya deneyimlerini metin düzlemine kendi toplumsal cinsiyet rolleriyle uyumlu süreçler aracılığıyla farklı biçimlerde kodladıklarını göstermektedir. Her ne kadar söz konusu seçimlerin metin düzleminde bilinçsizce yapılan seçimler olduğu düşünülse de aslında yapılan her dilsel seçim, yani süreç seçimi toplumsal cinsiyet ideolojisinin ve rollerinin nasıl içselleştirildiğini ve sürekli biçimde üretildiğini ortaya koymaktadır. Çalışmada erkek köşe yazarların maddesel süreçleri, kadın köşe yazarların ise zihinsel, ilişkisel ve davranışsal süreç türlerinin daha çok yeğlediklerini sonucuna ulaşılmıştır. Bu kapsamda erkek köşe yazarların maddesel süreçler aracılığıyla fiziksel dünya ile ilişkili olan anlamları ya da olayları ve süreci gerçekleştiren kılıcı rolünü açık biçimde vurgulayarak daha açık ve güçlü söylemi kullandıkları iddia edilebilir. Dolayısıyla bir medya söylem türü olan gazete köşe yazıları söyleminde erkek köşe yazarların oyun kurucu aktörler olarak karşımıza çıktığı ve toplumsal cinsiyet rollerine uygun 'güçlü' söylemi kullanarak medya söyleminde güç mekanizmalarını ellerinde tuttuğu belirtilebilir. Buna ek olarak erkek köşe yazarları gazete köşe yazıları söyleminin temel işlevi olan ikna edici söylemi kurgularken maddesel süreçler aracılığıyla bilgiyi örtükleştirmeden açık biçimde yapılandırmakta ve böylece okuyucu kitlesini, belki de farkında olmadan, belirli bir yönde etkileyerek alg1 yönetimini gerçekleştirmektedirler. $\mathrm{Bu}$ bağlamda erkek köşe yazarların anlam oluşturan ve güç mekanizmalarını yöneten aktörler olarak medya söyleminde yer aldığı düşünülebilir. Öte yandan kadın köşe yazarların ilişkisel, zihinsel ve davranışsal süreçleri daha çok kullanmaları, olaya ilişkin gerçekliği açıkça kurgulamaktan uzak durmalarıyla ilişkilendirilebilir. Kadın köşe yazarların daha çok algılayıcı ve gözlemci rolü üstlenerek olaya ilişkin gerçekliğin metin düzlemine aktarımında duygusal durum ve tutum sergiledikleri ve böylece eylemin devinim yönünden uzaklaşarak daha çok imgeler ve duyular aracılığıyla olayı yorumladıkları belirtilebilir. Ayrıca kadın köşe yazarlarının olgular arasında niteleme ve tanımlama ilişkisi kurarak bir takım anlamları ve yargıları sezdirimler aracılığıyla ilettikleri, böylece de bilgiyi örtükleştirme ya da bilgiyi paketleme stratejisi olarak söz konusu süreçleri daha çok yeğledikleri öne sürülebilir. Buradan hareketle kadın köşe yazarların gazete köşe yazılarının temel işlevi olan ikna edici söylemi kurgularken sürecin nasıl ve kim tarafindan gerçekleştiğine ilişkin anlamları vurgulamaktan kaçınarak daha çok durum tespitinde bulundukları ve böylece çatışma davranışından kaçındıkları öngörülebilir. Kadın köşe yazarlarının, dış dünya deneyimlerine ait zihinsel şemaları metin düzlemine aktarımında toplumsal cinsiyet rolleri bağlamında daha az özgüveni ve gücü yansıtan söylemi kurgulayarak toplumsal cinsiyete 
ilişkin var olan eşitsizliği sürekli biçimde yapılandırdıkları savlanabilir. Kısaca, dilde yapılan seçimlerin asla yansız ve masum olmadığ 1 , toplumsal bir pratik olan söylemin toplumsal cinsiyete ilişkin rollerin ve anlamların sürekli biçimde üretilmesine ve devam ettirilmesine önemli ölçüde aracılık ettiği ortaya konmaktadır. Toplumsal cinsiyet bağlamında gücün asimetrik dağılımının eşitsizlikleri sürekli biçimde yapılandırdığı ve bu kapsamda da toplumsal yapıda var olan erkek hegemonyasının korunmasına ve devam ettirilmesine hizmet ettiği açıktır (Fowler, 1991: 73-75). Eleştirel bakış açısı çerçevesinde dilsel yapıların işlevlerinin toplumsal ve kültürel yapılara dayandığg ve dil, güç ve ideoloji arasındaki ilişkinin belirgin bir şekilde kurgulandığı görülmektedir (Halliday, 1985). Yani toplumsal anlamlar ve onların metinsel düzlemde gerçekleşmesi güç ilişkilerinden bağımsız değildir.

Gazetenin politik ideolojisinin kadın ve erkek köşe yazarların süreç seçimlerine etkisi irdelendiğinde ise, politik ideolojinin süreç seçimine etki ettiği sonucuna ulaşılmıştır. Buna göre ilişkisel süreçlerin Laik ve Liberal görüşte kadın köşe yazarlar tarafından, İslami ideolojide ise erkek köşe yazarlar tarafından daha çok yeğlendiği, yani kadın köşe yazarların İslami ideolojide ilişkisel süreçleri daha az kullandığı ortaya konmuştur. Dolayısıyla bu durum İslami ideolojide erkek köşe yazarların düşünce dizgelerinin oluşumunda, savunduğu görüşün lehine yargılama ve değerlendirme edimlerini daha baskın gerçekleştirdiği ve böylece güç ideolojisini daha çok temsil ettikleri biçimde düşünülebilir. Buradan yola çıkarak İslami ideolojinin söylem yapısına etki ettiği ileri sürülebilir.

Bütün bilgilerden hareketle her toplumsal alanın, kurumun ve toplumsal pratiğin bir takım söylemsel ve iletişimsel şemalar aracılığıyla belirlendiğini ve aynı zamanda bu durumun toplumsal ve kültürel boyutta tanımlanan güç, egemenlik ve kontrol mekanizmalarına erişimi de belirlediğini söyleyebiliriz (van Dijk, 1996: 85-86). Eleştirel söylem çözümlemesi de bu bağlamda geçişlilik dizgesi aracılığıyla süreç seçimine etki eden toplumsal, kültürel, ideolojik ve politik etmenlerin metin içerisinde nasıl kurgulandığının ve medya söyleminde bu durum nasıl yansıtıldığının açığa çıkmasına olanak tanımaktadır. Elde edilen bulgular yalnızca çalışmanın veri tabanıyla sınırlıdır. Daha kapsamlı veri tabanıyla yapılacak çalışmalar sonucunda elde edilen bulgularla yorumlar genelleştirilebilir.

\section{Kaynaklar}

Ağaçsaban, S. (1988). Kız ve erkek öğrencilerde cinsiyetten kaynaklanan farklı dil kullanımı. (Yayımlanmamış Yüksek Lisans Tezi). Eskişehir: Anadolu Üniversitesi.

Aliefendioğlu, H. (1994). Konuşma dilinde cinsiyete dayalı farklılaşma: Kadın ve erkek dili. (Yayımlanmamış Yüksek Lisans Tezi). Ankara: Hacettepe Üniversitesi, Sosyal Bilimler Enstitüsü. 
Baş, M. (2009). Gender-preferential langugae use in the writing style of teenagers. (Unpublished Master Thesis). Ankara: Hacettepe Üniversitesi, Sosyal Bilimler Enstitüsü.

Baykal, N. (2014). Davos olayının köşe yazıları bağlamında söylem çözümlemesi. The Journal of Academic Social Science Studies, 24, 251-282.

Baysal, A. (1997). Cinsiyetin bir toplumdilbilimi değişkesi olarak dil kullanımına etkisi. Zeyrek, D. Zeyrek ve Ş. Ruhi (Yay. haz.). XI. Dilbilim Kurultayı: Bildiriler içinde (s. 237-245). Ankara: Şafak Matbaacılik.

Bayyurt, Y. (2000). Kim daha nazik? Erkekler mi, kadınlar mı?. A.S. Özsoy ve E. E. Taylan (Yay. haz.). XIII. Dilbilim Kurultay Bildirileri içinde (s. 155-167). İstanbul: Boğaziçi Üniversitesi Yayınevi.

Beydoğan, B. (2001). Attitudes toward women in managerial position: The effects of ambivalent sexism, patriarchy and gender differences on these attitudes. (Unpublished Master Thesis). Ankara: Orta Doğu Teknik Üniversitesi Sosyal Bilimler Enstitüsü.

Bingöl, O. (2014). Toplumsal cinsiyet olgusu ve Türkiye'de kadınlık. Karamanoğlu Mehmetbey Universitesi Sosyal ve Ekonomik Araştırmalar Dergisi, 3, 108-114.

Bloor, T. ve Bloor, M. (2004). The functional analysis of English. London: Arnold.

Bloor, T. Ve Bloor, M. (2007). The practice of ritical Discourse Analysis an introduction. London: Hodder Education.

Butler, J. (1999). Cinsiyet belası: Feminizm ve kimliğin altüst edilmesi. Çev. Başak Ertür. İstanbul Metis.

Chen, L. (2005). Transitivity in media texts: Negative verbal process sub-functions and narrator bias. IRAL, 43, 33-51.

Christie, C. (2000). Gender and language: Towards a feminist pragmatics. Edinburgh: Edinburgh University Press.

Çankaya, M. (2013). Geleneksel? Modern? Veya her ikisi? Türk televizyon reklamlarında toplumsal cinsiyet temsili. Süleyman Demirel Üniversitesi FenEdebiyat Fakültesi Sosyal Bilimler Dergisi, 30, 279-295.

Değer, A. (1998). Gazetelerdeki köşe yazılarında geçişlilik ve sözcük özellikleri. S. Yağcıoğlu (Yay. haz.). 1990 Sonrası Laik ve Antilaik Çatışmasında Farklı Söylemler içinde (s. 53-64). İzmir: Dokuz Eylül Yayınları.

Dökmen, Y. Z. (1999). Kendi cinsiyetindekilere ve diğer cinsiyettekilere ilişkin alg1, cinsiyet rolleri ve depresyon ilişkileri. Kriz Dergisi, 9, 9-19.

Dökmen, Y. Z. (1999). Toplumsal cinsiyet \& sosyal psikolojik açıklamalar. İstanbul: Remzi Kitapevi.

Duman, S. (1991). Türk kadınına verilen adlar. Dilbilim Araştırmaları, 40-42. Ankara: Hitit Yayınevi.

Eggins, S. (2004). An introduction to ystemic Functional Linguistics. New York: Continuum.

Ercan, G. S. (2003). Gazete köşe yazılarında dil kullanımı: Kaçınmalar ve cinsiyet değişkeni. (Yayımlanmamış Yüksek Lisans Tezi). İzmir: Dokuz Eylül Üniversitesi Sosyal Bilimler Enstitüsü.

Ercan, G. S. (2012). Gazete haber metinlerinde kadına karşı şiddet. Uluslararası Kadın Konferansl, 09/05/2012 - 11/05/2012, İzmir. 
Erdoğan, Y. (2014). Discursive construction and linguistics representations of gender in political discourses: A Critical Discourse Analysis of governmental public addresses in Turkey. (Unpublished Master Thesis). Ankara: Orta Doğu Teknik Üniversitesi.

Fairclough, N. (1992). Discourse and social change. Cambridge: Blackwell Publishers. Fairclough, N. (2003). Analysing discourse. New York: Routledge.

Fisher, A. (2011). Addicted to talk: Newspaper representations of female speaking subject. Working with English: Medieval and Modern Language, Literature and Drama, 7: 14-32.

Gallardo C. B. (2006). Analysis of literary work using Systemic-Functional Grammar. 33rd International Systemic Functional Congress, 2006.

Gazioğlu Terzi, E. (2013). Politik söylemde kadın: 1980'li yıllarda meclis tutanaklarında kadınlara ilişkin söylem. Karadeniz Dergisi, 21, 86-99.

Goddard, A. ve Patterson, L. M. (2000). Language and gender. London: Routledge.

Halliday, M. A. K. (1994). An introduction to Functional Grammar. London: Edward Arnold.

Halliday, M.A.K. ve Matthiessen, M.I.M. (2004). An introduction to Functional Grammar. New York: Oxford University Press.

Hart, C. (2014). Discourse, grammar and ideology. New York: Bloomsbury Publishing.

Hatipoğlu, Ç. (2006). Do Turkish males and females use different apologies for different types of offences?. S. Yağcioğlu ve A. Cem Değer (Yay. haz.). Advances in Turkish Linguistics içinde (s. 595-611). İzmir: Dokuz Eylül Yayınları.

Hodge, R. ve Kress, G. (1993). Language as ideology. London: Routledge.

Kamışl1, E. (2018). Toplumsal cinsiyet rolleri ve aile işlevselliğinin problem çözme becerilerine etkisi. (Yayımlanmamış Yüksek Lisans Tezi). İstabnul: İstanbul Ticaret Üniversitesi Sosyal Bilimler Enstitüsü.

Kamler, B. (1993). Constructing gender in the process writing classroom. Language Arts, 2: 95-103.

Kaplan, S. (2016). Anahaber bülteni içeriklerinde kadın temsil biçimleri. (Yayımlanmamış Yüksek Lisans Tezi). Lefkoşa: Yakın Doğu Üniversitesi.

Kaya, T. (2013). Televizyonda yayınlanan izdivaç programlarında toplumsal cinsiyetin temsili. Kadın Araştırmaları Dergisi, 13, 81-110.

Khan S. ve Rahman R. (2014). Power relationships and transitivity choices in Graham Greenes's Dream of Strange Land. Journal of Humanities and Social Sciences, 1: $35-44$.

König, G. (1992). Dil ve cins: Kadın ve erkeklerin dil kullanımı. Dil Araştırmaları, 2636. Ankara: Hitit Yayınevi.

Lakoff, R. (1975). Language and woman's place. New York: Harper and Row.

Litosseliti, L (2006). Gender and language: Theory and practice. New York: Routledge.

Matu, M.,Peter. (2008). Transitivity as a tool for ideological analysis. Journal of Third World Studies, 1, 199-211.

Oktar, L. (1998). Gazete söyleminde ideolojik yapılar. S. Yağcıoğlu (Yay. haz.). 1990 Sonrası Laik ve Antilaik Çatışmasında Farklı Söylemler içinde (s. 37-52). İzmir: Dokuz Eylül Yayınları.

Oktar, L. ve Değer, A. (1999). Gazete söyleminde kiplik ve işlevleri. Dilbilim Araştırmaları Dergisi, 10, 45-53. 
Oktar, L. (2001). The ideological organization of representational processes in the presentation of us and them. Discourse \& Society, 12, 313-346.

Öngen, B. ve Aytaç, S. (2013). Üniversite öğrencilerinin toplumsal cinsiyet rollerine ilişkin tutumları ve yaşam değerleri ilişkisi. Sosyoloji Konferansları, 48, 1-18.

Paltridge, B. (2006). Discourse analysis: An introduction. London: Continuum.

Phan, H. V. ve Nguyen, Tu, T. T. (2015) : A study of topology of behavioral clauses in English and Vietnamese in the light of Functional Grammar. International Journal of Language and Linguistics, 3, 347-352.

Sebzecioğlu, T. ve Özgür-Coşkun, S. (2015). Cinsiyete bağlı argo kullanımı üzerine bir twitter etiketi örneği. Uluslararası Dil, Edebiyat ve Halkbilimi Araştırmaları Dergisi, 5, 75-93.

Subaşı-Uzun, L. (1996). Anlamlandırma sürecinde kimi eğilimler ve cinsiyet değişkeni. Dilbilim Araştırmaları, 88-99. Ankara: Bizim Büro Basımevi.

Şimşek, B. (2006). Kadınlararası konuşma sürecinde toplumsal cinsiyetin dil üzerinden sergilenmesi. (Yayımlanmamış Yüksek Lisans Tezi). Ankara: Ankara Üniversitesi, Sosyal Bilimler Enstitüsü.Talbot, M. (2007). Media Discourse Representation and Interaction. Edinburgh: Edinburgh University Press.

Talbot, M. (2010). Language and gender. Cambridge: Polity Press.

van Dijk, T. A. (1987). News analysis: Case studies in international and tuitional news. Hillsdale, New Jersey: Lawrence Erlbaum Associates.

van Dijk, T. A. (1988). News as discourse. Hillsdale, New Jersey: Lawrence Erlbaum Associates.

van Dijk, T. A. (1996). Opinions and ideologies in editorials. Paper for the 4th International Symposium of Critical Discouse Analysis, Language, Social Life and Critical Thought. Athens.

van Dijk, T. A. (2008). Discourse and context. New York: Cambridge University Press. Vargün, B. (2016). Men's and women's position in the family in the context of social gender roles. Journal of Human Science, 13, 2952-2959.

Vatandaş, C. (2007). Toplumsal cinsiyet ve cinsiyet rollerinin algılanışı. Sosyoloji Konferanslart, 35, 29-56.

Yağcioğlu, S. ve Ercan, G. S. (2006). Hedging strategies in Turkish media discourse: Are they gender indexical?. S. Yağcığlu ve A. Cem Değer (Yay. haz.). Advances in Turkish Linguistics içinde (s. 623-642). İzmir: Dokuz Eylül Yayınları. 